\title{
Pengembangan Karakter Kewirausahaan Peserta Didik Sekolah Dasar Melalui Pendekatan Steams Berbasis Potensi Lokal
}

\author{
Rokhmaniyah ${ }^{1}$, Kartika Chrysti Suryandari ${ }^{2}$, Siti Fatimah ${ }^{3}$ \\ 1,2Universitas Sebelas Maret, ${ }^{3}$ Institut Agama Islam Nahdlatul Ulama Kebumen \\ rokhamaniyah@staff.uns.ac.id
}

\section{Article History \\ received 19/10/2021}

revised 15/11/2021 accepted 24/12/2021

\begin{abstract}
This study aims to develop the entrepreneurial character of elementary school students through a local potential-based Science, Technology, Art, Engineering, Mathematics, and Society (STEAMS) approach. This research is qualitative. The subjects of this study consisted of 152 students in 5 public elementary schools in the Kebumen area. The instruments used are test sheets, interview sheets, observation sheets, and questionnaire sheets. The data analysis technique uses the Miles and Huberman model which consists of data collection, data reduction, data display, and conclusions. Test the validity of this study using triangulation techniques. The results show that entrepreneurial characters that can be developed through the STEAMS approach include the courage to try, responsible, diligence, impassioned, independence, collaboration skill, communicate skills, critical and creative thinking skill.
\end{abstract}

Keywords: entrepreneurial character, STEAMS, local potential, elementary school

\begin{abstract}
Abstrak
Penelitian ini bertujuan untuk mengembangkan karakter kewirausahaan peserta didik sekolah dasar melalui pendekatan Science, Technology, Art, Engineering, Mathematics, and Society (STEAMS) berbasis potensi lokal. Penelitian ini merupakan penelitian kualitatif. Subyek penelitian ini terdiri dari 152 peserta didik di 5 sekolah dasar negeri daerah Kebumen. Instrumen yang digunakan berupa lembar tes, lembar wawancara, lembar observasi, dan lembar angket. Teknik analisis data menggunakan model Miles and Huberman yang terdiri dari data collection, data reduction, data display, and conclusions. Uji keabsahan penelitian ini menggunakan triangulasi teknik. Hasil penelitian menunjukkan karakter wirausaha yang dapat dikembangkan melalui pendekatan STEAMS meliputi berani mencoba, bertanggung jawab, tekun, pantang menyerah, kemandirian, kemampuan bekerja sama, kemampuan berkomunikasi, berpikir kritis dan kreatif.
\end{abstract}

Kata kunci: karakter kewirausahaan, STEAMS, potensi lokal, sekolah dasar 


\section{PENDAHULUAN}

Berdasarkan hasil survey, permintaan 10 kompetensi tertinggi dari pengusahapengusaha terkemuka di seluruh dunia pada tahun 2020 adalah memiliki kemampuan dan kemauan untuk memecahkan masalah yang kompleks, pemikiran kritis, kreativitas, manajemen, koordinasi, kerja sama, refleksi, pengambilan keputusan, orientasi pelayanan, negosiasi, dan flesibilitas kognitif (Stuntynska \& Umryk, 2019). Pengembangan kemampuan dan keterampilan harus menjadi perhatian bersama khususnya di era revolusi industri 4.0 agar dapat menciptakan sumber daya manusia yang berkualitas. Dalam dunia pendidikan, Indonesia telah menerapkan kurikulum 2013 dalam rangka menghadapi tantangan masa depan yang berkembang dengan sangat cepat dan kompleks. Pendidikan kewairausahaan menjadi langkah yang tepat dalam menciptakan sumber daya manusia yang mampu bersaing di dunia global. Kusdiyanti dkk (2019) menyatakan bahwa pendidikan kewirausahaan menjadi salah satu upaya penting yang harus dilakukan di era revolusi industri 4.0.

Berdasarkan hasil observasi dan wawancara dalam studi pendahuluan di beberapa sekolah dasar Kebumen menghasilkan temuan yaitu rendahnya jiwa wirausaha dengan persentase sebesar $38,75 \%$. Hasil observasi selama pembelajaran kurang menekankan aspek-aspek kewirausahaan sehingga peserta didik kurang memiliki daya kompetensi, peserta didik lebih cenderung meniru daripada menciptakan sebuah karya, keterampilan yang dikembangkan lebih terfokus pada keterampilan komunikasi dan kolaborasi sedangkan keterampilan berpikir kritis dan problem solving serta kreativitas dan inovasi kurang dikembangkan dengan optimal.

Penanaman nilai-nilai kewirausahaan sebaiknya ditanamkan sejak usia dini agar mampu membentuk karakter wirausaha yang kuat sejak kecil. Hassi (2016) menyatakan bahwa penanaman kewirausahaan perlu dilakukan dari usia dini dan terus dikembangkan sampai sekolah menengah. Dilanjutkan oleh Suzanti \& Maesaroh (2017) untuk memperkenalkan nilai-nilai kewirausahaan sejak usia dini adalah salah satu upaya paling penting dalam membentuk karakter generasi masa depan. Oleh karena itu, pembelajaran kewirausahaan pada anak lebih mengarah pada perubahan mental anak sehingga pendidikan kewirausahaan akan membentuk karakter anak yang kuat seperti menjadi kreatif, disiplin, kritis, mampu menyelesaikan masalah, mampu berkomunikasi, menghargai waktu, mengendalikan diri, dan sebagainya.

Salah satu upaya yang dapat dilakukan oleh satuan pendidikan dalam mengembangkan jiwa wirausaha peserta didik adalah dengan menerapkan pembelajaran Science, Technology, Art, Engineering, Mathematics, and Society (STEAMS). Pendekatan STEAMS merupakan pendekatan yang dikembangkan dari istilah STEAM (Science, Technology, Engineering, Art, and Mathematics). Tambahan aspek Society pada STEAM dimaksudkan untuk menambah pengetahuan tentang isuisu sosial yang ada di masyarakat sehingga dapat menumbuhkan kepedulian terhadap masyarakat dan lingkungan.

Kusdiyanti, dkk (2019) menyebutkan bahwa pendekatan STEAM merupakan pendekatan yang tepat dalam meningkatkan keterampilan kewirausahaan untuk menciptakan output secara real. Anisa, dkk (2019) menyebutkan pendekatan STEAM mampu mendorong siswa untuk memahami setiap komponen STEAM di setiap pembelajaran sehingga menghasilkan pengusaha yang handal di masa depan. Dilanjutkan oleh Stuntynska \& Umryk (2019) menjelaskan bahwa STEM/STEAM adalah konsep dan sistem pendidikan yang digunakan untuk mengembangkan keterampilan yang dibutuhkan anak-anak dan remaja untuk menjadi sukses di abad 21 dan berkontribusi pada pengembangan inovatif. Selain menggunakan pendekatan STEAMS, pembelajaran dengan mengintegrasikan muatan-muatan potensi lokal dapat mengembangkan karakter kewirausahaan. Malik \& Mulyono (2017) menyebutkan bahwa potensi alam yang melimpah dapat dikembangkan dan dioptimalkan untuk 
menghasilkan sebuah produk yang layak dijual. Dilanjutkan dalam Sari, dkk (2017) menghasilkan temuan bahwa model pembelajaran berbasis potensi lokal efektif mampu mengembangkan minat peserta didik untuk berwirausaha.

Berdasarkan latar belakang di atas, pengembangan karakter kewirausahaan di sekolah dasar perlu dilakukan melalui pendekatan STEAMS melalui pemanfaatan potensi lokal. Hasil ini dapat dijadikan pedoman dalam mengembangkan pendidikan kewirusahaan khususnya di sekolah dasar Kebumen.

\section{METODE}

Penelitian ini merupakan penelitian kualitatif dengan subyek penelitian adalah 152 peserta didik di lima sekolah dasar negeri di Kebumen. Pemilihan subjek penelitian mengacu kepada kondisi geografis sehingga siswa yang dijadikan sebagai subjek penelitian adalah siswa yang bersekolah di sekolah dasar di daerah pegunungan, pedesaaan, perkotaan, dan pesisir. Penelitian ini dilakukan selama 3 bulan. Instrumen yang digunakan berupa lembar tes, lembar angket, lembar wawancara, dan lembar observasi. Lembar tes berupa bentuk soal pilihan ganda dengan jumlah item 15 butir soal yang mencakup konsep mata pelajaran tematik dan kewirausahaan. Lembar angket, lembar wawancara, dan lembar observasi disusun dengan memperhatikan karakter kewirausahaan yang meliputi berani mencoba, bertanggung jawab, tekun, pantang menyerah, kemandirian, kemampuan bekerja sama, kemampuan berkomunikasi, berpikir kritis dan kreatif.

Pengembangan jiwa wirausaha dengan menggunakan pendekatan STEAMS selain mangalokasikan khusus jam pelajaran kewirausahaan juga diintegrasikan pada pembelajaran tematik. Sehingga pengembangan jiwa wirausaha selalu ditekankan di setiap kegiatan belajar mengajar. Teknik analisis data menggunakan model Miles and Huberman yang terdiri dari data collection, data reduction, data display, and conclusions.

\section{HASIL DAN PEMBAHASAN}

Penerapan pembelajaran STEAMS di Sekolah Dasar kabupaten Kebumen menitikberatkan pada karakter wirausaha. Karakter wirausaha yang dikembangkan meliputi berani mencoba, bertanggung jawab, tekun, pantang menyerah, kemandirian, kemampuan bekerja sama, kemampuan berkomunikasi, berpikir kritis dan kreatif. Karakter kewirausahaan tersebut dikembangkan dengan menggunakan tahapan pendekatan STEAMS yaitu science, technology, engineering, mathematics, society).

Pembelajaran STEAMS diawali dengan menganalisis potensi lokal yang ada di daerah, yaitu di daerah perkotaan, pedesaan, pesisir pantai, dan pegunungan. Peserta didik dilatih merancang produk inovatif berbahan dasar potensi lokal kabupaten Kebumen. Sebagai contoh produk yang dikembangkan di daerah pesisir seperti anyaman mendong yang biasanya untuk membuat tikar, maka akan dibuat sandal hotel dengan dihiasi manik-manik dan tali rami. Selanjutnya wilayah pegunungan mengenalkan potensi lokal dari limbah kayu dan ranting-ranting untuk dibuat kolase dan mozaik tiga dimensi. Hasil karya yang dibuat peserta didik berupa tempat pensil karton yang dihiasi dengan limbah kayu, dan tali rami sebagai kolase. Potensi lokal wilayah pedesaan berupa hasil pertanian yaitu kacang hijau, padi, jagung, sepet dari kelapa dapat dibuat sebuah produk seperti tempat koin.

Rancangan didiskusikan dengan guru dan teman sejawat. Aktivitas analisis dikerjakan dalam lembar LKPD secara berkelompok. Peserta didik dilibatkan untuk mengemas prosuk dan memberikan label. Produk yang sudah dikemas selanjutnya dipresentasikan oleh peserta didik di depan kelas. Selanjutnya, peserta didik dilatih 
untuk menjual produk kepada masyarakat sekolah. Kegiatan ini dilaksanakan dengan tujuan agar peserta didik berani, percaya diri, dan mampu berkomunikasi untuk menawarkan produk kepada orang lain.

Pendekatan STEAMS diterapkan pada pembelajaran tematik dan kewirausahaan sesuai dengan aspeknya yang mengacu pada kompetensi dasar. Contoh penerapan STEAMS pada pembelajaran Kewirausahaan, yaitu: Science diterapkan dengan cara guru memberikan pengetahuan dasar tentang pengertian potensi lokal, selanjutnya mengamati berbagai jenis potensi lokal secara langsung atau tidak langsung. Technology: mengamati sumberdaya alam menggunakan internet atau melalui surat kabar dan majalah. Engenering: merancang dan membuat produk. Art: pengetahuan seni diberikan pada peserta didik dan prakteknya untuk menghasilkan kreativitas produk agar memiliki kualitas yang layak jual. Mathematic: peserta didik diajarkan untuk menghitung keuntungan dan kerugian penjualan produk dan menganalisis bentuk ukuran dari sebuah produk. Society: mengajarkan peserta didik untuk bekerja sama dengan teman dalam menyelesaikan proyek.

Berdasarkan hasil analisis tes, dari kelima sekolah dasar negeri yang diamati, rerata skor nilai kewirausahaan paling tinggi adalah 72,5 sedangkan paling rendah adalah 50 . Hasil ini menunjukkan bahwa tingkat pemahaman siswa tentang kewirausahaan menunjukkan kategori cukup baik. Bentuk soal berjumlah 15 item pertanyaan dengan bentuk soal pilihan ganda. Sedangkan berdasarkan hasil observasi, siswa mampu berkomunikasi dengan baik dengan prosentase diatas $80 \%$. Keterampilan berkomunikasi juga terlihat baik saat mengerjakan proyek bersama membuat produk, peserta didik sudah bisa membagi masing-masing tugas individu dan terdapat komunikasi yang baik selama kegiatan kelompok.

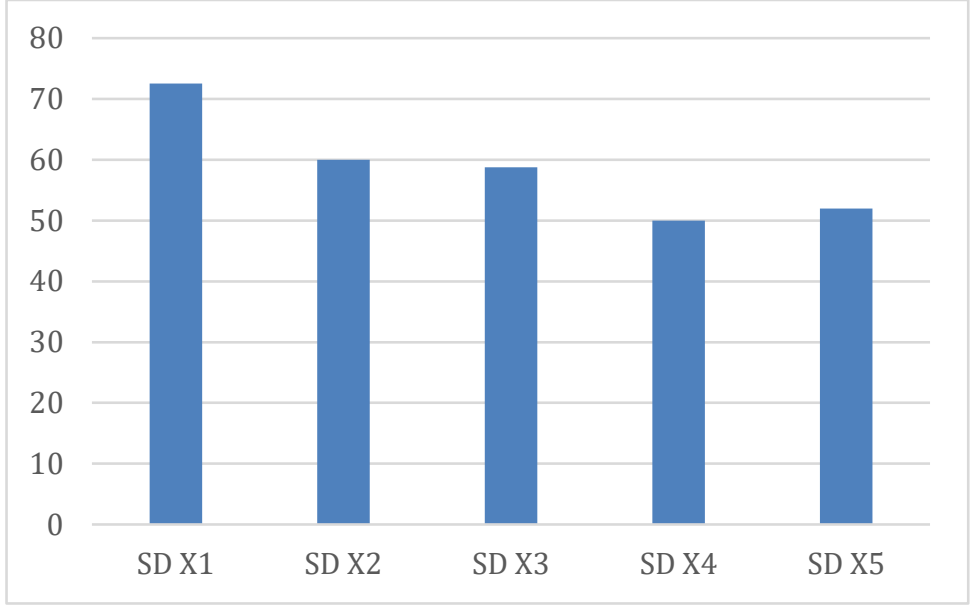

\section{Gambar 1. Nilai rata-rata kewirausahaan menggunakan STEAMS}

Gambar 1 menunjukkan bahwa rerata skor nilai kewirausahaan paling tinggi adalah 72,5 sedangkan paling rendah adalah 50 . Berdasarkan hasil observasi, peserta didik sudah mulai terbiasa dengan pembelajaran berbasis STEAMS yang output dari setiap pembelajaran adalah menghasilkan sebuah produk. Agar pendidikan karakter kewirausahaan dapat berkembang dengan optimal, perlu adanya pembelajaran yang menekankan pada pembuatan sebuah proyek.

Aspek kerjasama yang diobservasi adalah kontribusi setiap anggota kelompok, tanggung jawab setiap anggota untuk menyelesaikan tugas, penyamaan pendapat seluruh anggota, saling membantu sesama anggota. Berdasarkan observasi semua peserta didik menunjukkan gradasi kerjasama yang berbeda. Berdasarkan observasi pengamatan langsung dikelas dapat dilihat bahwa kemampuan kerja sama siswa kelas IV dalam pembelajaran kewirausahaan secara umum berkriteria baik. Pada saat 
pelaksanaan penelitian dilangsungkan kegiatan kelompok untuk membuat produk gelang dan kalung dari manik-manik.

Indikator percaya diri meliputi percaya pada kemampuan diri sendiri, bertindak mandiri, memiliki rasa positif terhadap diri sendiri, berani mengungkapkan pendapat. Berdasarkan hasil observasi, sikap percaya diri siswa menunjukkan kategori baik. Hasil angket menunjukkan bahwa sebanyak $98,50 \%$ siswa merasa optimis untuk menjadi anak yang sukses, sebanyak $95,68 \%$ siswa senang untuk berkomunikasi dengan orang lain sehingga mampu memiliki komunikasi yang baik, senang bertanya kepada guru ketika tidak memahami arahan yang disampaikan guru, senang berdiskusi dengan sesama teman dalam merancang desain produk yang akan dibuat, serta mampu memiliki kepercayaan diri yang baik dalam memasarkan sebuah produk.

Indikator kemandirian meliputi percaya diri, mampu bekerja sendiri, menghargai waktu, bertanggungjawab, hasrat bersaing untuk maju, mampu mengambil keputusan. Aspek kejujuran dalam pembelajaran kewirausahaan menjadi salah satu sikap yang harus dimiliki untuk menjadi seorang wirausaha. Dalam pembelajaran, aspek kejujuran dapat terlihat pada saat siswa melakukan proses pemasaran sebuah produk. Sebagai contoh bahwa hasil karya yang telah dibuat merupakan hasil karya sendiri dan bukan hasil karya dari orang lain/orang tua. Ketika memasarkan, siswa menyampaikan informasi bahwa hasil karya yang telah dibuat adalah hasil karya buatan sendiri. Berdasarkan hasil angket, sebanyak $98,45 \%$ siswa menyatakan bahwa kejujuran adalah hal yang sangat penting dalam setiap aktivitas.

Aspek keterampilan kreatif dan inovatif terdiri dari berpikir lancar (fluency), berpikir luwes (flexibility), berpikir orisinil (originality), berpikir elaboratif (elaboration). Dalam mengembangkan keterampilan berpikir kreatif dan inovatif, guru menggunakan teknik brainstorming. Melalui brainstorming siswa akan terbiasa untuk selalu berpikir dan memberikan ide-ide/pendapat sesuai dengan pertanyaan-pertanyaan/permasalahan dari guru. Selain keempat hal tersebut, kemampuan siswa dalam mendesain/membuat pola produk sampai pembuatan produk yang memiliki keindahan dan layak dijual juga merupakan penilaian pada aspek kreatif dan inovatif. Berdasarkan hasil observasi, siswa merasa tertantang dan lebih semangat dalam membuat sebuah produk dengan hasil imajinasi masing-masing. Hasil angket menunjukkan bahwa sebanyak $98,68 \%$ siswa senang dalam membuat inovasi sebuah produk, sebanyak $95,50 \%$ siswa mampu membuat desain sebuah produk dengan baik, dan sebanyak $96,70 \%$ siswa merasa senang dengan sesuatu hal yang baru (menyukai tantangan baru) seperti membuat produk dan memasarkan produk yang layak dijual.

Selain aspek di atas, beberapa jiwa wirausaha yang berkembang adalah bekerja keras, pandai memanfaatkan peluang, keterampilan memecahkan masalah, dan berani menanggung resiko. Aspek bekerja keras dapat dilihat saat siswa membuat produk dengan semangat dan pantang menyerah. Berdasarkan hasil observasi, siswa mampu membuat produk dengan semangat dan pantang menyerah. Ketika siswa membuat produk dari genitri saat membuat aksesoris diperlukan ketekunan dan ketepatan dalam membuat aksesoris yang berdaya jual tinggi. Ketika siswa memasukkan genitri dan manik-manik dalam sebuah tali/benang, terkadang setelah selesai banyak yang talinya putus sehingga produk yang telah dibuat berantakan dan harus dimulai dari awal. Hal ini posisi guru selalu menanamkan sikap kerja keras dan pantang menyerah dalam membuat sebuah produk. Selain itu, proses menyulam sandal yang terbuat dari mendong dan menempelkan biji-bijian serta ranting-ranting kayu untuk menghasilkan sebuah produk merupakan salah satu aspek dalam sikap bekerja keras. Berdasarkan hasil angket, sebanyak $97,80 \%$ siswa memiliki sikap yang tidak mudah menyerah dalam mengerjakan sebuah tugas.

Aspek pandai memanfaatkan peluang diberikan saat guru memberikan motivasi kepada siswa dengan mencontohkan salah satu pengusaha cilik yang bernama 
Almeyda Nayara (Naya) yang mampu membaca peluang dengan baik yaitu dengan menjual dan membuat permainan Slime sehingga mampu menghasilkan omzet sebesar Rp 60 juta rupiah per bulan. Permainan Slime merupakan salah satu jenis permainan yang sedang hits dikalangan anak-anak. Melalui kisah tersebut, guru memberikan motivasi kepada anak-anak untuk mampu membaca peluang dengan baik.

Hasil angket menunjukkan bahwa sebanyak $78,60 \%$ siswa mampu membaca peluang dengan tepat dan menyusun target-target yang akan dicapai. Hasil ini mengindikasikan bahwa aspek membaca peluang dan menyusun target-target yang akan dicapai masih harus perlu ditingkatkan dan dikembangkan setiap saat. Dalam upaya mengembangkan sikap mampu membaca peluang dengan baik siswa dapat membaca literatur seperti di media massa, TV, dan internet, serta mengamati kondisi di lingkungan sekitar. Sedangkan upaya dalam penyusunan target-target yang akan dicapai, siswa perlu selalu diarahkan untuk menuliskan target-target apa saja yang akan dicapai tiap hari, kemudian siswa diarahkan untuk mengevaluasi setiap target yang telah dicapai dan target-target yang belum tercapai. Sebagai contoh, ketika menjual sebuah produk, target yang dicapai adalah dapat menjual semua produk yang telah dibuat. Namun, ketika ada produk yang tidak laku maka siswa perlu diarahkan untuk membuat evaluasi.

Aspek yang selanjutnya adalah sikap berani menanggung resiko. Sikap ini dikembangkan dalam setiap pembelajaran dengan cara memberikan kesempatan kepada siswa untuk memberikan argumentasi/pendapat tanpa takut jika jawaban tersebut salah, memberikan kesempatan kepada siswa untuk mencoba membuat produk tanpa takut bahwa produk yang dibuat akan gagal, dan tidak mudah putus asa ketika produk yang dibuat tidak sesuai dengan harapan. Sebagai contoh ketika siswa berlatih menjual produk, terdapat produk yang tidak terjual, maka siswa diarahkan untuk selalu semangat dan mengevaluasi mengapa produk yang dibuat tidak terjual.

Aspek keterampilan memecahkan masalah terdiri dari lima indikator yang diamati, yaitu mengidentifikasi masalah, memeriksa masalah, merencanakan solusi, melaksanakan rencana yang telah dibuat, dan mengevaluasi. Pembelajaran kewirausahaan berbasis STEAMS sangat mampu mengembangkan sikap keterampilan memecahkan masalah. Diawal pembelajaran guru selalu memberikan sebuah permasalahan yang nantinya siswa diminta untuk menganalisis masalah tersebut. Sebagai contoh dalam pembelajaran, guru menampilkan beberapa produk potensi lokal daerah Kebumen yang layak dan tidak layak dijual. Aktivitas pembelajaran yang dapat mengembangkan keterampilan memecahkan masalah siswa. Guru memberikan tiga jenis gambar produk daerah Kebumen. Kemudian siswa diarahkan untuk menganalisis ketiga gambar tersebut, "manakah gambar yang menarik dan layak untuk dijual?". Kemudian guru menanyakan mengapa produk tersebut yang paling menarik dan layak untuk dijual. Selanjutnya siswa diberikan bahan-bahan untuk membuat aksesoris seperti genitri dan manik-manik yang berbeda. Guru menanyakan kepada siswa, "dengan bahan-bahan ini apakah yang dapat kalian buat?". Beberapa siswa mampu menjawab bahwa dengan bahan-bahan ini bisa dibuat kalung, gelang, gantungan kunci, penjepit rambut, tasbih, dan sebagainya. Proses aktivitas ini mampu mendorong siswa untuk menyelesaikan masalah. 


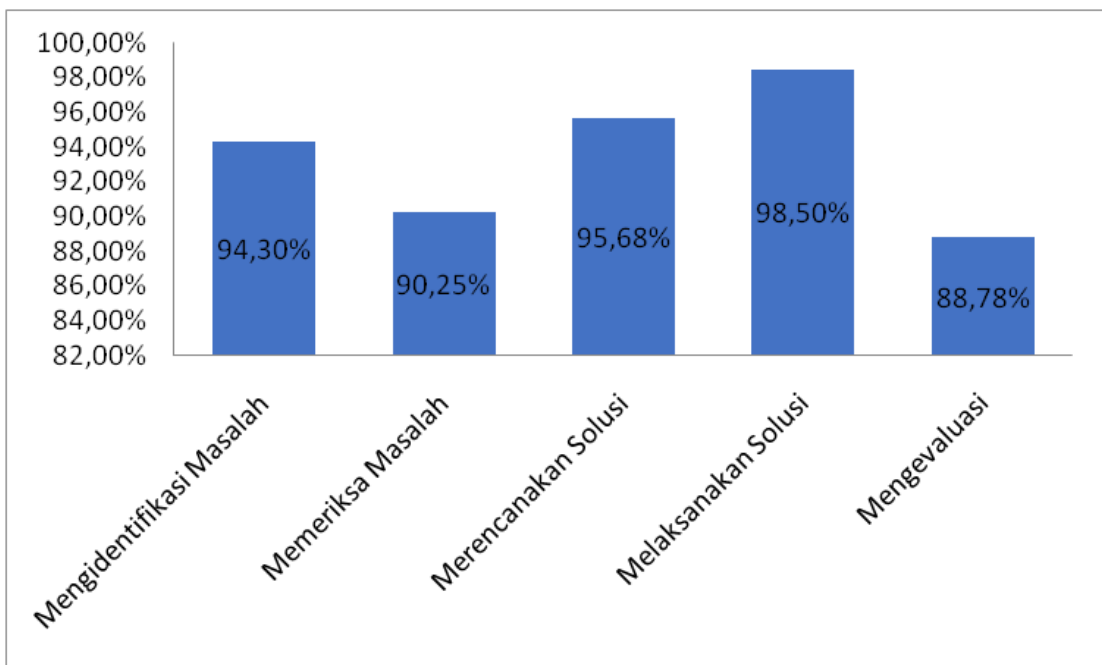

\section{Gambar 2. Perbandingan Persentase Tiap Indikator Keterampilan Menyelesaikan Masalah}

Berdasarkan gambar 2 dapat dijelaskan bahwa aspek melaksanakan solusi mendapatkan peresentase yang paling tinggi yaitu 98,50\%, sedangkan pada aspek mengevaluasi mendapatkan persentase yang paling rendah yaitu $88,78 \%$.

Aspek keterampilan membuat produk menjadi capaian akhir dalam pembelajaran kewirausahaan. Siswa membuat produk dari bahan-bahan potensi lokal daerah Kebumen. Sebagai contoh, potensi lokal di darah pesisir dapat berupa produk dri bahan mendong dan biji-bijian. Sebelum siswa diarahkan untuk membat poduk, guru memberikan arahan bahwa produk yang dibuat harus menarik dan memiliki nilai jual. Misalnya, ketika membuat aksesoris dari genitri dan mank-manik siswa diarahkan untuk memperhatikan pola dan penentuan jenis mank-maniknya dilihat dari keseimbangannya. Selain membuat eksesoris, siswa juga diarahkan untuk membuat celengan yang terbuat dari hiasan biji-bijian. Sebelum membuat celengan, siswa diarahkan untuk memuat polanya. Dalam membuat pola guru juga mengarahkan siswa untuk tidak asal membuat polanya. Diusahakan pola yang dibuat seimbang dan mudah untuk ditempel dengan bijibijian.

Secara keseluruhan dari hasil analisis menunjukkan bahwa pembelajaran dengan menggunakan pendekatan STEAMS dapat digunakan dalam mengembangkan jiwa wirausaha peserta didik. Penelitian Ubawuike (2018) menghasilkan temuan terdapat hubungan antara inovasi, kewirausahaan, dan pendidikan STEAMS. Pendidikan STEAMS dapat mengembangkan keterampilan, pengetahuan, dan kompetensi yang diperlukan inovasif, dan penciptaan keunggulan kompetitif dalam ekonomi berbasis pengetahuan. Hasil penelitian dari Gozales (2019) yang menjelaskan bahwa program pendidikan kewirausahaan melalui pendidikan STEAMS memiliki dampak positif pada persepsi peluang wirausaha individu, kesadaran lingkungan wirausaha, dan self-efficacy. Ergun (2019) menyebutkan bahwa untuk membentuk individu yang memiliki keterampilan wirausaha, lingkungan belajar harus diciptakan dan guru yang sebagai seorang pendidik harus memiliki keterampilan wirausaha. Dalam hal ini pendidikan STEAMS adalah pembelajaran yang dapat digunakan untuk membentuk lingkungan wirausaha baik untuk guru dan juga siswa. Dilanjutkan dari hasil penelitian Rokhmaniyah, dkk (2020) menghasilkan temuan bahwa pendekatan STEAMS tepat digunakan dalam mengembangan jiwa wirausaha peserta didik sekolah dasar dengan memaksimalkan potensi lokal yang ada.

STEAMS merupakan pendekatan kontekstual yang mengajak peserta didik untuk memahami fenomena-fenomena yang terjadi yang dekat dengan dirinya dan mendorong siswa untuk belajar mengeksplor semua kemampuan yang dimiliki dengan 
cara masing-masing (Yakman \& Lee, 2012). Liritzis (2018) menyatakan bahwa hasil akhir dari STEAMS ini adalah menghasilkan siswa yang berani menanggung resiko, tidak mudah putus asa, terlibat aktif dalam pembelajaran, bertahan dalam menyelesaikan masalah, meningkatkan kolaborasi, dan bekerja secara kreatif dengan menarik dan menyenangkan. Beberapa pendapat tersebut menjelaskan bahwa pendekatan STEAMS sejalan/tepat digunakan untuk mengembangkan jiwa wirausaha dimana karakter wirausaha siswa meliputi kreatif dan inovatif, mau bekerja keras, pandai memecahkan masalah, mampu membaca dan memanfaatkan peluang dengan tepat, dan berani menanggung resiko.

Ubawuike (2018) menekankan bahwa agar inovasi dan kewirausahaan berdampak pada perkembangan ekonomi, kuncinya adalah melalui pendidikan STEAMS. Pendidikan STEAMS mampu mengembangkan keterampilan-keterampilan seperti keterampilan memecahkan masalah (problem solving skill), keterampilan analisis dan merencanakan proyek, keterampilan matematika untuk pengukuran dan perhitungan, keterampilan kerjasama dan komunikasi, keterampilan kepemimpinan, dan keterampilan teknis untuk menyelesaikan masalah. Hal ini didukung dalam penelitian Liritzis (2018) yang menyatakan bahwa salah satu hasil akhir dari STEAM ini adalah menghasilkan siswa yang memiliki sikap tidak mudah putus asa.

Adanya sikap bekerja keras mampu mendorong untuk menghasilkan sebuah inovasi. Hal ini sejalan dengan penelitian Mohd, dkk (2015) bahwa sikap bekerja keras berhubungan positif dengan orientasi inovasi dalam pembelajaran kewirausahaan. Selain kerja keras, kedisiplinan memiliki hubungan yang positif dengan inovasi. Dijelaskan pula bahwa inovasi memerlukan rencana strategis yang sistematis dan kerja keras, dan individu yang menghargai disiplin dan kerja keras percaya bahwa dengan menjadi inovatif, seseorang dapat sukses dalam bisnis/berwirausaha.

Jiwa wirausaha lain yang dapat dikembangkan adalah problem solving skill. Problem solving skill merupakan salah satu keterampilan yang harus dimiliki oleh siswa pada abad 21. Pembelajaran kewirausahaan berbasis STEAMS mampu mendorong siswa untuk memiliki keterampilan memecahkan masalah. Hasil ini sejalan dengan penelitian Kim, dkk (2018) bahwa kemampuan pemecahan masalah secara positif mempengaruhi perilaku inovasi dan persepsi peluang dalam berwirausaha. Dijelaskan pula bahwa keterampilan memecahkan masalah menjadi kunci sikap inovatif dalam menanggapi perubahan cepat dengan kemampuan untuk menemukan berbagai alternatif dan memprediksi sebuah hasil.

Kemampuan membaca peluang bagi individu menjadi sangat penting dalam berwirausaha. Kim, dkk (2018) menjelaskan bahwa kemampuan membaca peluang adalah bagaimana menemukan dan memanfaatkan peluang kreatif yang menciptakan nilai dan keuntungan baru dan merupakan tujuan akhir dari pendidikan kewirausahaan. Individu yang mampu membaca peluang memiliki kemampuan yang lebih baik dalam melakukan sebuah inovasi. Hal ini sejalan dengan penelitian Kim, dkk (2018) bahwa perilaku inovasi menjadi penentu dalam kemampuan membaca peluang menjadi lebih baik. Dijelaskan pula bahwa melalui pembelajaran kewirausahaan mampu meningkatkan kemampuan membaca peluang dengan inovatif. Berdasarkan hasil analisis observasi, kemampuan membaca peluang siswa dalam pembelajaran kewirausahaan berbasis STEAMS dikembangkan dengan cara membaca berbagai literatur, misalnya internet, media massa, lingkungan sekitar, dan TV/radio.

Sikap berani menanggung resiko menjadi salah satu hasil dalam pembelajaran STEAM. Liritzis (2018) menyatakan bahwa salah satu hasil akhir dari STEAM adalah menghasilkan siswa yang berani menanggung resiko. Sikap berani menanggung resiko berhubungan erat dengan kesuksesan yang diraih. Individu yang memiliki sikap berani menanggung resiko akan lebih mampu mendapatkan kesuksesan daripada individu yang yang takut untuk melakukan sebuah inovasi. Berani menanggung resiko juga 
berhubungan erat dengan kemampuan inovatif setiap individu. Individu yang memiliki sikap berani menanggung resiko, jika mengalami kegagalan akan selalu mengevaluasi. Poses evaluasi ini akan mengembangkan kemampuan inovatif. Keberanian dalam mengambil resiko terkait langsung dengan kepercayaan pada diri sendiri. Semakin besar keyakinan seseorang pada kemampuan sendiri, maka semakin besar pula keberaniannya dalam mengambil resiko yang diperhitungkannya sebagai tindakan yang kreatif inovatif.

\section{SIMPULAN}

Hasil penelitian menunjukkan karakter wirausaha yang dapat dikembangkan melalui pendekatan STEAMS berbasis potensi lokal meliputi berani mencoba, bertanggung jawab, tekun, pantang menyerah, kemandirian, kemampuan bekerja sama, kemampuan berkomunikasi, berpikir kritis dan kreatif. Potensi lokal yang digunakan mengikuti karakteristik daerah yang ada di Kebumen.

Saran dari penelitian ini adalah mata pelajaran kewirausahaan sebaiknya dapat menjadi mata pelajaran tersendiri agar dapat fokus mengembangkan kewirausahaan peserta didik. Pembelajaran tematik juga diharapkan dapat menjadi solusi dalam mengembangkan jiwa wirausaha mengingat pembelajaran tematik menjadi pembalajaran utama di sekolah dasar.

\section{DAFTAR PUSTAKA}

Aryani, R. 2019. Entrepreneurship Learning Model Based on Local Wisdom for Increasing Student Creative Business. Indonesian Journal of Contemporary Education. Vol 1 (1): 24-31.

Darmawan, I., \& Soetjipto, B.E. 2016. The Implementation of Project Based Learning to Improve Entrepreneurial Intention and Entrepreneurship Learning Outcome of Economics Education Student. Journal of Business and Management, Vol 18 (10): 98-102.

Ergun, S. S. 2019. Examining the STEM Awareness and Entrepreneurship Levels of PreService Science Teachers. Journal of Education and Training Studies. Vol 7 (3): 142-149.

Hassi, A. 2016. Effectiveness of Early Entrepreneurship Education at the Primary School Level: Evidence From a Field Research in Morocco. Citizenship, Social and Economics Education. Vol 15 (2): 83-103.

Kim, J.Y., Choi, D.S., Sung. C.S., \& Park, J.Y. 2018. The Role of problem Solving Ability on Innovative Behavior and Opportunity Recognition in University Students. Journal of Open Innovative: Technology, Market, and Complexity. Vol 4 (4): 1-13.

Kusdiyanti, H., Febrianto, I., \& Wijaya, R. 2019. Enchancing Teacher Competitiveness Of Entrepreneurship Through Augmented Reality Module: STEAM Approach. International Journal Of Scientific \& Technology Research. Vol 8 (12): 3387-3391.

Liritzis, I. 2018. STEMAC (Science, Technology, Engineering, Mathematics for Arts \& Culture: The Emergence of a New Pedagogical Discipline. Scientific Culture. Vol 4 (2): 73-76.

Malik, A. \& Mulyono, S.E. (2017). Pengembangan Kewirausahaan Berbasis Potensi Lokal melalui Pemberdayaan Masyarakat. Journal of Nonformal Education and Community Empowerment.Vol 1 (1): 88-101.

Mohd, R., Kamaruddin, B.H., Yahya, K.K., \& Sanidasm E. 2015. Can Value of Honesty, hard Work, Loyalty, and Discipline Predict Entrepreneurial Orientation of Muslim Owner Managers?. Journal of Emerging Economies and Islamic Research. Vol 3 (1): 1-13. 
Rokhmaniyah, Suryandari, K.C., \& Fatimah, S. (2020). Steams-Based Entrepreneur Curriculum Development by Empowering Local Potential for Elementary Students. International Journal of Science and Applied Science: Conference Series. Vol X (X): 66-77.

Stuntynska, U. \& Umryk,M. 2019. Learning Startups as a Project Based Approach in Stem Education. E-Learning and STEM Education. Vol 11. 529-555.

Suzanti, L. \& Maesaroh, S. 2018. Entrepreneurship Learning for Early Childhood A Case Study of Children Age $4-5$ in TK Khalifah Ciracas Serang. Proceedings of the 2nd International Conference on Economic Education and Entrepreneurship. 403-410.

Tahir, T., \& Hasan, M. 2019. Vocational High School Student Entrepreneurship Competency Based on Local Wisdom. Advances in Economics, Business and Management Research. Vol 75: 227-230.

Thiagarajan. 1974. Instructional Development for Training Teachers of Exceptional Children. Minnesota: Minneapolis.

Ubawuike, A.B. 2018. Science, Technology, Engineering and Mathematics (STEM) Education: A Catalyst for Entrepreneruship and Economics Growth in Nigeria. International Journal of Education. Vol 7 (1): 1-11.

Yakman, G., \& Lee, H. 2012. Exploring the Exemplary STEAM Education in the U.S. as a Practical Educational Framework for Korea. J. Korea Assoc. Sci. Edu. Vol 32 (6): 1072-1086. 